\title{
PENGARUH METODE PENGERINGAN TERHADAP KUALITAS SERBUK SERESAH Enhalus acoroides DARI PANTAI TAWANG PACITAN
}

\author{
Farida Huriawati ${ }^{1)}$, Wachidatul Linda Yuhanna ${ }^{2)}$, Tantri Mayasari3 ${ }^{3)}$ \\ ${ }^{1,2,3)}$ IKIP PGRI Madiun, Jalan Setia Budi No. 85 Madiun, \\ linda.yuhanna.wiguno@gmail.com
}

\begin{abstract}
Pacitan regency has potential commodities sea flora. One of them is E. acoroides. E. acoroides utilization as a source of chemicals and pharmaceuticals requires proper treatment to hold up for a long time and do not change the content therein. One process that is usually given is the process of heating to slow the chemical and biological processes in the material, so that the material be durable. This research method involves eksperimen.Step in this research are 1) preparation E. acoroides litter, 2) pulverizing E. acoroides litter, 3) analysis of litter powder quality includes analysis of water content, ash content, fat and starch content. Results from this study is the drying process is done in 2 ways using the oven and sunlight. Using the oven drying process causes browning by reactions of non-enzymatic. Using the oven drying process which takes place at elevated temperatures causes hardening case, that the surface is dry food once even hardened while the inside is still moist. The quality of the feasibility of production of powder litter seagrass by sun drying method moisture content of $14.76 \%, 18.83 \%$ ash, starch $9.88 \%$ and $0.54 \%$ fat. Drying by oven water level is $23.66 \%, 19.39 \%$ ash, starch $8.73 \%$ and $0.74 \%$ fat
\end{abstract}

Keywords: Drying, litter, E. acoroides, Tawang

\begin{abstract}
Abstrak - Kabupaten pacitan memiliki komoditas flora laut yang potensial. Salah satunya adalah E. acoroides. Pemanfaatan E. acoroides sebagai sumber bahan kimia dan obat-obatan membutuhkan pengolahan yang tepat sehingga mampu tahan dalam waktu yang lama. Salah satu proses yang biasa diberikan adalah proses pemanasan untuk memperlambat proses kimia dan biologi pada bahan, sehingga bahan menjadi tahan lama. Metode penelitian ini menggunakan metode eksperimen.Tahapan penelitian meliputi pengambilan dan preparasi E. acoroides, pembuatan serbuk seresah E. acoroides, analisa kualitas serbuk seresah E. acoroides yang meliputi analisa kadar air, kadar abu, kadar lemak, dan kadar pati. Hasil dari penelitian ini adalah proses pengeringan dilakukan dengan 2 cara yaitu menggunakan oven dan sinar matahari. Proses pengeringan menggunakan oven yang berlangsung pada suhu yang tinggi menyebabkan terjadinya case hardening, yaitu bagian permukaan bahan pangan sudah kering sekali bahkan mengeras sedangkan bagian dalamnya masih basah. Kualitas kelayakan hasil produksi serbuk seresah lamun dengan metode pengeringan sinar matahari kadar air 14,76\%, kadar abu 18,83\%, kadar pati 9,88\% dan kadar lemak $0,54 \%$. Pengeringan menggunakan oven kadar airnya $23,66 \%$, kadar abu $19,39 \%$, kadar pati $8,73 \%$ dan kadar lemak $0,74 \%$.
\end{abstract}

Kata kunci: Pengeringan, Serbuk, E. acoroides, Tawang 


\section{PENDAHULUAN}

Indonesia mempunyai perairan laut yang kaya akan berbagai biota laut baik flora maupun fauna membentuk dinamika kehidupan di laut yang saling berkesinambungan (Nybakken, 2007). Ekosistem laut merupakan suatu kumpulan integral dari berbagai komponen abiotik (fisika-kimia) dan biotik (organisme hidup) yang berkaitan satu sama lain dan saling berinteraksi membentuk suatu unit fungsional. Nontji (2009) laut sebagai penyedia sumber daya alam yang produktif baik sebagai sumber pangan, tambang mineral, dan energi, media komunikasi maupun kawasan rekreasi atau pariwisata. Sehingga wilayah pesisir dan lautan merupakan tumpuan harapan manusia dalam pemenuhan kebutuhan dimasa datang. Kabupaten Pacitan menyimpan potensi sumber daya kelautan, baik hayati ataupun non-hayati yang cukup menjanjikan untuk dikelola.

Salah satu biota laut yang dapat dimanfaatkan adalah lamun (seagrass). Berbagai spesies lamun mempunyai produktivitas primer di perairan dangkal seluruh dunia dan merupakan sumber makanan penting bagi banyak organisme. Lamun tumbuh di perairan dangkal dan dalam zona fotik (Badui, 2001; Nybakken, 2007; Hartati et.al, 2012). Lamun di Indonesia terdapat tujuh marga yaitu Enhalus, Thalassia, Halophila, Halodule, Cymodocea, Syringodium dan Thalassodendron (Nontji, 2003)

Dahuri (2009), (Nontji, 2009) dan Steven (2012) menyampaikan bahwa Beberapa fungsi ekologi lamun adalah 1) sumber utama produktivitas primer, 2) sumber makanan penting bagi organisme, 3) menstabilkan dasar yang lunak melalui sistem perakaran yang padat dan saling menyilang, 4) tempat berlindung organisme perairan pantai, 5) Tempat pembesaran bagi beberapa spesies yang menghabiskan masa dewasanya di lamun seperti udang dan ikan baronang (Siganus sp.), 6) peredam arus sehingga perairan di sekitarnya menjadi tenang dan 7) pelindung organisme dari terik matahari yang intensitasnya tinggi.

Lamun dapat dimanfaatkan oleh masyarakat baik secara tradisional maupun secara modern (Badui, 2010; Setyawati et.al, 2003). Pemanfaatan lamun selama ini dimanfaatkan untuk kompos dan pupuk, cerutu, mainan anak-anak, keranjang, kasur dan jaring ikan. Sedangkan secara modern telah ada beberapa penelitian tentang pemanfaatan lamun sebagai penyaring limbah, stabilizator pantai, bahan untuk pabrik kertas, makanan sehat, sumber bahan kimia, dan obat-obatan.

Salah satu lamun potensial untuk sumber industri bahan kimia adalah $E$. acoroides (Zakaria, 2015; Steven, 2012). Pemanfaatan lamun khususnya E. acoroides sebagai sumber bahan kimia dan obatobatan membutuhkan pengolahan yang tepat dan baik sehingga mampu tahan dalam waktu yang relatif lama dan tidak merubah kandungan yang ada didalamnya. Salah satu proses yang biasa diberikan adalah proses pemanasan. Proses pemanasan dilakukan untuk memperlambat proses kimia dan biologi pada bahan, sehingga bahan menjadi tahan lama. Proses pemanasan ini rentan sekali terjadi kerusakan dan penurunan kualitas bahan.

Pengeringan merupakan proses penurunan kadar air bahan sampai mencapai kadar air tertentu sehingga dapat memperlambat laju kerusakan produk akibat aktivitas biologi dan kimia. Pengeringan pada dasarnya merupakan proses perpindahan energi yang digunakan untuk menguapkan air yang berada dalam bahan, sehingga mencapai kadar air tertentu 
agar kerusakan bahan pangan dapat diperlambat. Kelembapan udara pengering harus memenuhi syarat yaitu sebesar 5560\% (Pinem, 2004).

Menurut Huda (2008) bahwa pengeringan merupakan penghilangan air dari suatu bahan. Proses utama yang terjadi paska proses pengeringan adalah penguapan. Penguapan terjadi apabila air yang dikandung oleh suatu bahan teruap, yaitu apabila panas diberikan kepada bahan tersebut. Panas ini dapat diberikan melalui berbagai sumber, seperti kayu api, minyak dan gas, arang baru ataupun tenaga surya. Pengeringan dapat dilakukan dengan memanfaatkan energi surya (pengeringan alami) dan dapat juga dilakukan dengan menggunakan peralatan khusus yang digerakkan dengan tenaga listrik.

Faktor-faktor pada pengeringan yang mempengaruhi mutu bahan adalah luas permukaan bahan pangan, suhu pengeringan, aliran udara, tekanan uap air, sumber energi yang digunakan dan jenis bahan yang akan dikeringkan. Pengeringan akan menyebabkan tejadinya perubahan warna, tekstur dan aroma bahan pangan. Pengeringan menyebabkan kadar air bahan pangan menjadi rendah yang juga akan menyebabkan zat-zat yang terdapat pada bahan pangan seperti protein, lemak, karbohidrat dan mineral akan lebih terkonsentrasi.

Pada dasarnya, kadar air dapat dibagi menjadi dua golongan yaitu pengeringan alami (natural drying) dan pengeringan buatan (artificial drying) atau pengeringan mekanis (mechanical drying) (Lidiasari et.al, 2010). Pengeringan alami menggunakan sinar matahari yang mengakibatkan case hardening (permukaan mengeras). Pengeringan artificial dilakukan dengan menggunakan alat dan dapat dimanipulasi oleh manusia.
Tujuan dari penelitian ini adalah untuk 1) mengetahui metode pengeringan serbuk seresah E. acoroides, dan 2) mengetahui kadar kualitas serbuk seresah E.acoroides yang mencakup analisis kadar air, kadar abu, kadar lemak, dan kadar pati.

\section{METODE PENELITIAN}

Penelitian ini dilakukan selama 5 bulan. Penelitian ini dilakukan di pantai Tawang Pacitan, laboratorium Pendidikan Fisika, laboratorium Pendidikan Biologi IKIP PGRI Madiun.

Alat-alat yang digunakan pada pembuatan serbuk seresah $E$. acoroides ini antara lain neraca analitik, pemanas furnace, blender, bunsen, penyaring, gunting, pisau, cawan porselin, spatula, thermometer, pengaduk merkuri, pengaduk kaca, gelas arloji, erlenmeyer, pipet volume, gelas ukur, pipet tetes, kertas saring, gelas beaker, corong kaca, botol semprot, pipet ukur, labu ukur, labu lemak, tabung soxhlet. Bahanbahan yang digunakan adalah seresah $E$. acoroides dari pantai Tawang Kabupaten Pacitan, asam klorida $(\mathrm{HCl})$, Natrium Hidroksida $(\mathrm{NaOH})$, aquadest, benzena. Tahapan penelitian meliputi pengambilan dan preparasi sampel, pembuatan serbuk seresah lamun, analisa kualitas serbuk seresah lamun yang meliputi analisa kadar air, kadar abu, kadar lemak, dan kadar pati.

Tahapan penelitian ini adalah:

1. Pengambilan seresah E. acoroides dari pantai Tawang Pacitan.

2. Pembuatan serbuk seresah $E$. acoroides

Sampel dicuci dengan air tawar yang mengalir untuk menghilangkan pasir dan garam, kemudian proses pengeringan menggunakan sinar matahari langsung dan menggunakan oven. Sampel yang telah dikeringkan dihaluskan menggunakan blender dan kemudian disaring $(0,25-0,5 \mathrm{~mm})$. 
3. Analisa kadar air serbuk seresah E. acoroides

Analisis kadar air dilakukan mengacu pada SNI 01-2356-2006. Cawan porselen dikeringkan dalam oven selama 30 menit, lalu didinginkan dalam desikator selama 15 menit. Sampel ditimbang sebanyak 5 gram dalam cawan dan dikeringkan dalam oven pada suhu $100^{\circ} \mathrm{C}$ dalam tekanan tidak lebih dari $10 \mathrm{mmHg}$ selama 5 jam atau sampai beratnya konstan. Cawan beserta isinya kemudian didinginkan dalam desikator dan ditimbang. Perhitungan kadar air sebagai berikut.

$$
\text { Kadar Air }(\%)=\frac{B-C}{B-A} \times 100 \%
$$

Keterangan:

( $\mathrm{A}=$ berat cawan kosong ( $\mathrm{g}$ ), $\mathrm{B}$ =berat cawan + sampel awal (g), C = berat cawan + sampel kering (g))

4. Analisa kadar abu serbuk seresah E. acoroides

Cawan pengabuan dikeringkan di dalam oven selama satu jam pada suhu $105^{\circ} \mathrm{C}$, didinginkan selama 15 menit di dalam desikator dan ditimbang sampai berat yang konstan. Sampel sebanyak 5 gram dimasukkan ke dalam cawan pengabuan dan dipijarkan di atas nyala api bunsen hingga tidak berasap. Sampel dimasukkan ke dalam tanur pengabuan dengan suhu $600^{\circ} \mathrm{C}$ selama 1 jam, kemudian ditimbang hingga berat yang konstan. Kadar abu ditentukan dengan rumus:

$$
\operatorname{Kadar} A b u(\%)=\frac{C-A}{B-A} \times 100 \%
$$

Keterangan:

$(\mathrm{A}=$ Berat cawan porselen kosong $(\mathrm{g}), \mathrm{B}=$
Berat cawan dengan sampel (g), C= Berat cawan dengan sampel dikeringkan (g))

5. Analisa kadar lemak serbuk seresah $E$. acoroides

Sampel seberat 5 gram (W1) dimasukkan ke dalam kertas saring pada kedua ujung bungkus ditutup dengan kapas bebas lemak dan selanjutnya dimasukkan ke dalam selongsong lemak, kemudian sampel yang telah dibungkus dimasukkan ke dalam labu lemak yang sudah ditimbang berat tetapnya (W2) dan disambungkan dengan tabung soxhlet. Selongsong lemak dimasukkan ke dalam ruang ekstraktor tabung soxhlet dan disiram dengan pelarut lemak (benzena), kemudian dilakukan refluks selama 6 jam. Pelarut lemak yang ada dalam labu lemak didestilasi hingga semua pelarut lemak menguap. Pada saat destilasi pelarut akan tertampung di ruang ekstraktor, pelarut dikeluarkan sehingga tidak kembali ke dalam labu lemak, selanjutnya labu lemak dikeringkan dalam oven pada suhu $105^{\circ} \mathrm{C}$, setelah itu labu didinginkan dalam desikator sampai beratnya konstan (W3). Perhitungan kadar lemak sebagai berikut.

$\operatorname{Kadar} \operatorname{Lemak}(\%)=\frac{W 3-W 2}{W 1} \times 100 \%$

\section{Keterangan}

$(\mathrm{W} 1=$ Berat sampel $(\mathrm{g}), \mathrm{W} 2=$ Berat labu lemak kosong (g),W3= Berat labu lemak dengan lemak (g)

6. Analisa kadar pati serbuk seresah $E$. acoroides

Menimbang 5 gram serbuk dan ekstrak seresah Enhalus acoroides, dilarutkan dalam $50 \mathrm{ml}$ aquadest dan diaduk selama 1 jam, kemudian menyaringnya dengan kertas saring dan 
dicuci dengan aquadest sampai volume filtrat $250 \mathrm{ml}$. Filtrat ini mengandung karbohidrat yang larut dan dibuang. Residu dipindahkan dari kertas saring kedalam erlenmeyer dengan pencucian $200 \mathrm{ml}$ aquadest dan menambahkan $1 \mathrm{ml} \mathrm{HCl} \mathrm{25 \% .} \mathrm{Menutupnya} \mathrm{dengan}$ pendingin balik dan memanaskannya di atas waterbath selama 2,5 jam. Setelah dingin, dinetralkan dengan larutan $\mathrm{NaOH} 45 \%$ dan diencerkan sampai volume $500 \mathrm{ml}$ kemudian disaring dan ditentukan kadar gula dari filtrat yang diperoleh.

Analisis data menggunakan deskriptif kuantitatif dengan mendasar pada data eksperimen. Setelah itu dideskriptifkan dan dianalisis secara mendalam.

\section{HASIL DAN PEMBAHASAN}

Penelitian ini berfokus pada metode pengeringan serbuk seresah E. acoroides, dan analisis kualitas serbuk seresah $E$. acoroides yang mencakup analisis kadar air, kadar abu, kadar lemak, dan kadar pati. Adapun hasil dan pembahasan sebagai berikut:

\section{Pengeringan seresah E. acoroides}

Proses pengeringan seresah $E$. acoroides dalam penelitian ini melalui dua metode pengeringan yaitu sinar matahari langsung dan oven. Pengeringan seresah E. acoroides dengan sinar matahari langsung dilakukan dalam waktu satu minggu, sedangkan pengeringan seresah E. acoroides dengan oven hanya dalam waktu 30 menit dengan suhu $120^{\circ} \mathrm{C}$.

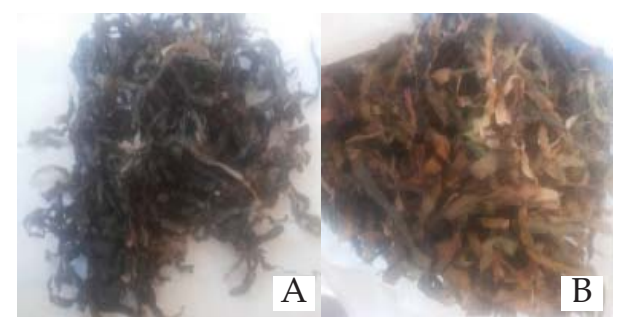

Gambar 1. Hasil pengeringan seresah $E$.

Acoroides menggunakan sinar matahari (a)

dan oven $(b)$

Kedua proses pengeringan tersebut memiliki kelebihan dan kekurangan. Keuntungan pengeringan dengan menggunakan sinar matahari tidak diperlukan penanganan khusus dan tidak mahal serta dapat dikerjakan oleh siapa saja. Namun kelemahan dari pengeringan dengan menggunakan sinar matahari berjalan sangat lambat sehingga terjadi pembusukan di beberapa bagian sebelum menjadi kering. Hasil pengeringan pun tidak merata dan pelaksanaan tergantung oleh alam. Kesulitan-kesulitan yang didapat pada pengeringan secara alami, maka digunakan pengeringan oven yang memiliki kelebihan sebagai berikut: 1) Suhu, kelembaban, dan kecepatan angin dapat diukur, 2) Sanitasi dan hygiene dapat lebih mudah dikendalikan. Metode oven juga memiliki beberapa kekurangan, yaitu bahan lain ikut menguap, terjadi penguraian karbohidrat menghasilkan air yang ikut terhitung, ada air yang terikat kuat pada bahan yang tidak terhitung. 


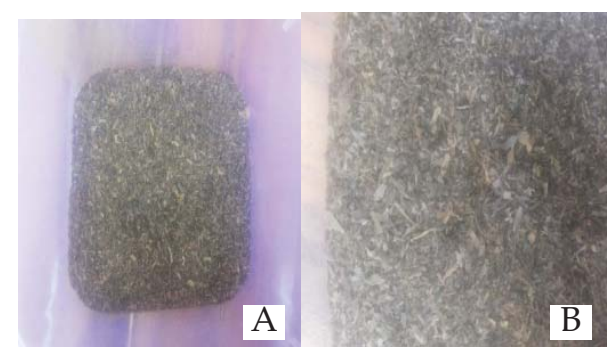

Gambar 2. Serbuk seresah E. Acoroides menggunakan sinar matahari (a) dan oven (b)

Kedua proses pengeringan seresah E. acoroides terjadi perubahan warna, tekstur dan aroma. Seresah E. acoroides yang telah dikeringkan mengalami pencoklatan (browning) yang disebabkan oleh reaksi-reaksi non-enzimatik. Tekstur dari seresah E. acoroides menjadi keras akibat dari penurunan kadar air oleh proses pengeringan. Pengeringan sinar matahari langsung warnanya lebih memudar sedangkan pada proses pengeringan oven warna hijau dari seresah E. acoroides masih nampak. Proses pengeringan menggunakan oven yang berlangsung pada suhu yang tinggi dan pada waktu yang singkat menyebabkan terjadinya case hardening, yaitu bagian permukaan E. acoroides sudah kering sekali bahkan mengeras sedangkan bagian dalamnya masih basah.

2. Pengujian Kualitas Serbuk Seresah E. acoroides

Uji kualitas serbuk seresah lamun tersebut dilakukan pengukuran kadar air, kadar abu, kadar pati, dan kadar lemak.

a. Kadar Air

Kadar air tertinggi serbuk seresah E. acoroides $(23,66 \%)$ diperoleh dari pengeringan oven dengan suhu $120^{\circ} \mathrm{C}$ selama 30 menit dan berbeda sangat nyata dengan pengeringan matahari selama 1 minggu (14,76\%). Data tersebut menunjukan bahwa perlakuan suhu dan lama pengeringan memberikan pengaruh yang signifikan. Perlakuan suhu yang tinggi pada pengeringan oven yaitu $120^{\circ} \mathrm{C}$ tidak menurunkan kadar air yang lebih besar dari pengeringan matahari yang memiliki suhu ratarata $32^{\circ} \mathrm{C}$. Hal tersebut disebabkan pengaruh lama pengeringan yang sangat berbeda jauh yaitu 1minggu untuk pengeringan matahari dan cuma 30 menit untuk peneringan oven. Semakin lama pengeringan berlangsung (1 minggu dibanding 30 menit) maka kadar air dalam seresah lamun semakin berkurang. Proses pengeringan sangat dipengaruhi oleh suhu dan lama pengeringan. Akan tetapi pengeringan dengan menggunakan suhu yang terlalu tinggi dapat mengakibatkan pengeringan yang tidak merata, akan tetapi pengeringan suhu rendah juga kurang efisien karena membutuhkan waktu yang relatif lebih lama.

Tabel 1. Data Hasil Uji Serbuk Seresah E. acoroides Pantai Tawang Pacitan

\begin{tabular}{ccccc}
\hline $\begin{array}{c}\text { Metode } \\
\text { Pengeringan }\end{array}$ & Kadar Air & Kadar Abu & Kadar Pati & Kadar Lemak \\
\hline Matahari & $14,76 \%$ & $18,83 \%$ & $9,88 \%$ & $0,54 \%$ \\
Oven & $23,66 \%$ & $19,39 \%$ & $8,73 \%$ & $0,74 \%$ \\
\hline
\end{tabular}




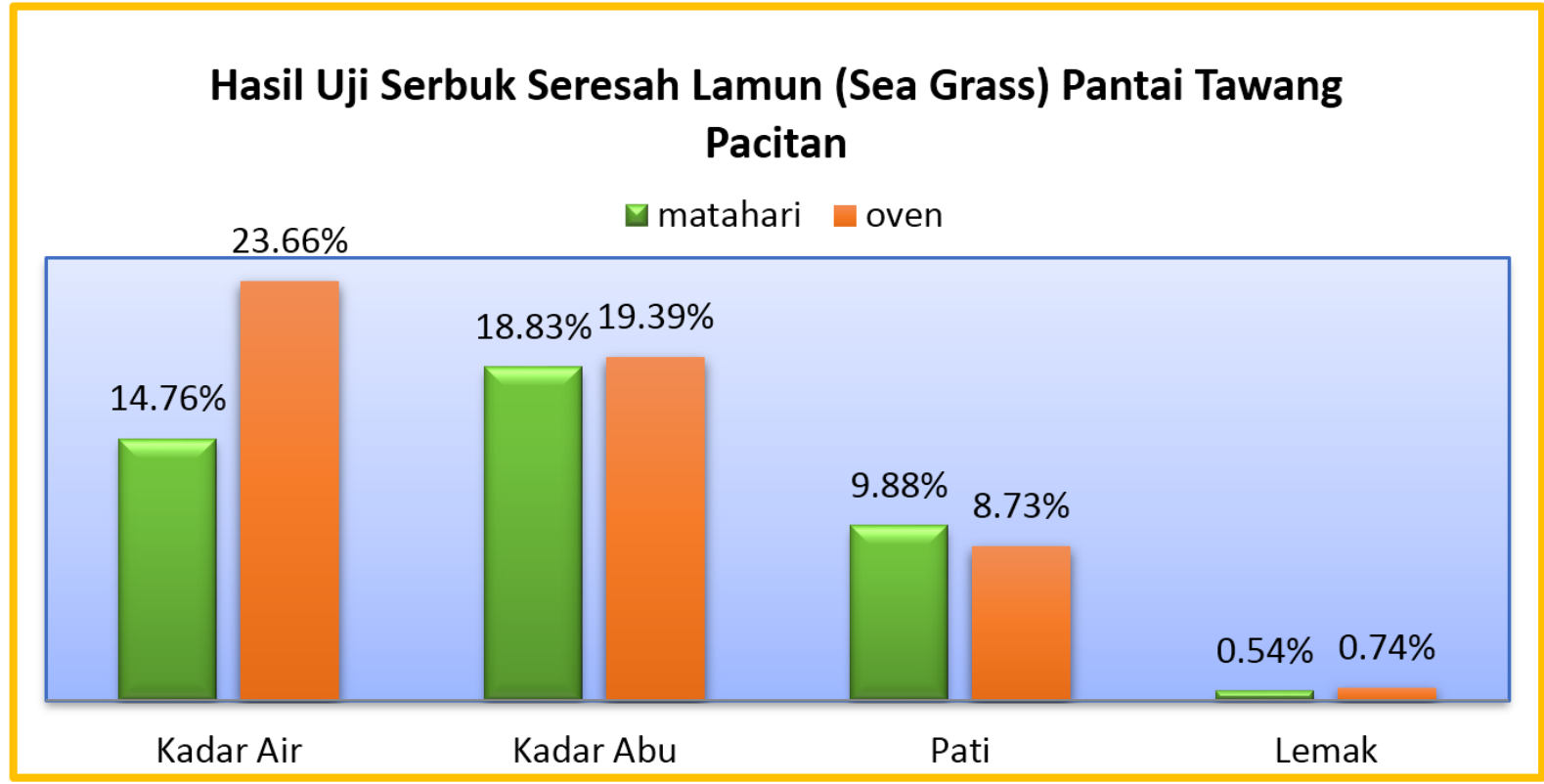

Gambar 3. Grafik Hasil Uji Serbuk Seresah E. acoroides Pantai Tawang Pacitan

b. Kadar Abu

Berdasarkan data yang diatas, Kadar abu yang lebih tinggi diperoleh pada pengeringan oven dengan suhu $120^{\circ} \mathrm{C}$ yaitu $19,39 \%$, sedangkan kadar abu pada pengeringan matahari selama 1 minggu dengan suhu ratarata $32^{\circ} \mathrm{C}$ yaitu $18,83 \%$. Bertambahnya suhu pengeringan maka kadar abu cenderung meningkat. Kandungan abu yang terlalu tinggi dapat menghasilkan warna yang kurang baik pada bahan.

c. Kadar Pati

Hasil analisis terhadap kandungan pati menunjukkan bahwa suhu pengeringan berpengaruh terhadap rendemen kandungan pati serbuk seresah E. acoroides. Pada pengeringan oven selama 30 menit dengan suhu $120^{\circ} \mathrm{C}$ menghasilkan kadar pati lebih rendah yaitu sebesar $8,73 \%$, sedangkan kadar pati lebih tinggi didapat dengan pengeringan matahari selama 1 minggu dengan suhu pengeringan rata-rata $32^{\circ} \mathrm{C}$ yaitu sebesar 9,88\%. Semakin tinggi suhu pengeringan maka kadar pati semakin menurun. Hal ini diduga karena perlakuan suhu yang tinggi akan mengakibatkan rusaknya sebagian molekul pati saat pengeringan. Selain itu perbedaan kadar pati diduga juga dapat terjadi karena proses pengolahan, seperti halnya proses penggilingan pada saat pembuatan pati dapat menghilangkan kadar pati mencapai $13-20 \%$.

d. Kadar Lemak

Lemak merupakan zat makanan yang penting untuk kesehatan tubuh manusia. Selain itu lemak juga terdapat pada hampir semua bahan pangan dengan kandungan yang berbeda-beda (Badui, 2010). Hasil analisis terhadap kandungan lemak serbuk seresah E. acoroides menunjukkan bahwa suhu dan waktu 
pengeringan berpengaruh terhadap kandungan lemak serbuk seresah E. acoroides. Pada pengeringan oven selama 30 menit dengan suhu $120^{\circ} \mathrm{C}$ menghasilkan kadar lemak lebih tinggi yaitu sebesar $0,74 \%$, sedangkan kadar lemak lebih rendah didapat dengan pengeringan matahari selama 1 minggu dengan suhu pengeringan rata-rata $32^{\circ} \mathrm{C}$ yaitu sebesar $0,54 \%$. Hal tersebut disebabkan waktu pengeringan seresah E. acoroides dengan metode langsung dengan sinar matahari yang jauh lebih lama yaitu 1 minggu walaupun suhunya relatif lebih rendah daripada pengeringan oven, sehingga kerusakan lemak lebih besar terjadi. Hal ini senada dengan penelitian Badui (2010) bahwa buah lamun E. acoroides mempunyai kandungan nutrisi lemak 0,76\% yang dapat digunakan sebagai salah satu alternatif bahan pangan.

Perlakuan suhu dan waktu pengolahan pada bahan dapat menyebabkan lemak mengalami kerusakan dan jumlahnya menurun. Hal ini sesuai dengan pendapat Setyati et.al (2003), tingkat kerusakan lemak bervariasi tergantung suhu yang digunakan dan waktu pengolahan. Semakin tinggi suhu dan lama waktu yang digunakan, maka kerusakan lemak akan semakin meningkat.

\section{SIMPULAN, SARAN \\ DAN REKOMENDASI}

Berdasarkan analisis data penelitian, maka dapat disimpulkan bahwa Proses pengeringan seresah $E$. acoroides dilakukan dengan 2 cara yaitu menggunakan oven dan sinar matahari langsung. Proses pengeringan menggunakan oven yang berlangsung pada suhu yang tinggi dan pada waktu yang singkat menyebabkan terjadinya case hardening, yaitu bagian permukaan bahan pangan sudah kering sekali bahkan mengeras sedangkan bagian dalamnya masih basah.

Analisis kualitas serbuk seresah E. acoroides dengan metode pengeringan sinar matahari kadar air 14,76\%, kadar abu 18,83\%, kadar pati 9,88\% dan kadar lemak $0,54 \%$. Pengeringan menggunakan oven kadar airnya 23,66\%, kadar abu 19,39\%, kadar pati 8,73\% dan kadar lemak 0,74\%. Proses pengeringan seresah E. acoroides yang lebih efektif dan efisien adalah menggunakan oven karena prosesnya lebih cepat dan higienis dengan hasil uji yang baik.

Saran dari penelitian ini adalah adanya kajian dan penelitian lanjutan yang lebih menyeluruh untuk optimalisasi seresah E. acoroides. Selain itu juga perlu pengembangan ke arah yang lebih luas seperti bidang industri dan bidang lainnya.

\section{DAFTAR PUSTAKA}

Badui. D., (2010). Analisis Kadar Gizi Buah Lamun (Enhalus acoroides) dan Hubungan Antara Pengetahuan, Persepsi, dengan Pemanfaatan Buah Lamun Sebagai Sumber Makanan Alternatif Masyarakat Desa Waai Kec.Salahutu, Kab. Maluku Tengah.

Dahuri, R. (2009). Kondisi Padang Lamun (Seagrass) di Teluk Banten 19982001. Pusat Penelitian OseanografiLembaga Ilmu Pengetahuan Indonesia.

Hartati, R., Djunaedi A., Hariyadi, Mujiyarto. (2012). Struktur Komunitas Padang Lamun Di Perairan Pulau Kumbang Kepulauan Karimunjawa. Jurnal Ilmu Kelautan Universitas Diponegoro Vol 17 (4):217-255 
Huda, D.K., Muhammad, Cahyono, Bambang, Limantara, Leenawaty. (2008). Pengaruh Proses Pengeringan terhadap Kandungan Kurkuminoid dalam Rimpang Temulawak. Seminar Tugas Akhir S1 Jurusan Kimia FMIPA Universitas Diponegoro. Semarang

Nontji, A. (2009). Laut Nusantara. Djambatan, Jakarta

Nybakken. (2007). Seagrass Ecology. Cambridge University Press

Setyati, W. A., Subagiyo, A. Ridlo. (2003). Studi Potensi Berbagai Jenis Lamun Sebagai Sumber Makanan Kesehatan: Analisis Proksimat.
Laporan Akhir. Fakultas Perikanan dan Ilmu Kelautan Universitas Diponegoro

Steven. (2012). Pengaruh Perbedaan Substrat Terhadap Pertumbuhan Semaian dari Biji Lamun Enhalus acoroides. Skripsi. Jurusan Ilmu Kelautan. Universitas Hasanuddin Makassar.

Zakaria. (2015). Pengaruh Substrat Terhadap Laju Pertumbuhan Daun Lamun (Enhalus acoroides) di Perairan Senggarang Kecamatan Tanjungpinang. Skripsi. Fakultas Ilmu Kelautan dan Perikanan Universitas Maritim Raja Ali Haji. 